\title{
MEASURING PERCEIVED LIBRARY SERVICE QUALITY
}

\author{
Fitroh Adhilla
}

Ahmad Dahlan University

fitrohadhilla@yahoo.co.id

\begin{abstract}
ABSTRAK
Bisnis inti dari sebuah lembaga akademis adalah untuk memberikan pengetahuan dan praktek keilmuwan terbaru, sehingga perpustakaan memainkan peran penting dalam membantu kemajuan mahasiswa. Kepuasan pengguna perpustakaan tergantung pada kualitas layanan yang diberikan. Penelitian tentang kepuasan pengguna perpustakaan Universitas Ahmad Dahlan Kampus 1 ini menggunakan responden sebanyak 250 mahasiswa. Hasil uji validitas menunjukkan bahwa semua variabel dapat dikatakan reliabel. Hasil uji secara parsial menunjukkan, kemampuan individu dalam mencari informasi dan akses informasi memiliki pengaruh positif signifikan pada kepuasaan pengguna sedangkan layanan tidak memiliki pengaruh positif signifikan pada kepuasan pengguna.
\end{abstract}

Keywords: service quality at library, customer satisfaction, academic library.

\section{INTRODUCE}

At this time librarians are redefining their roles; seeing an expansion of the knowledge, abilities, skills, and habits of mind required for them to fill those roles; and engaging in profound change within their organizations as they cope with new methods of learning, information-seeking, source preferences, and forms of competition, as well as an ever-changing electronic information environment and changing expectations on the part of those they serve (Hernon and Altman, 2010). Many in the profession strongly believe that only they, the professionals, have the expertise to assess the quality of library service.

Customers are more than a source for data collection; they are the reason for libraries' existence. It is important (if not essential) to listen to, and learn from, customers and to use the insights gained to improve services. A number of libraries have ignored customers because they perceive customers as a captive audience. This book dispels that notion as it enumerates the many competitors poised to challenge the library's perceived monopoly. Many library surveys ask about customer satisfaction, sometimes in a general context and sometimes in relation to specific services. Usually the questions about satisfaction allow for scaled responses (e.g., ranging from not satisfied at all through partially satisfied to satisfied and completely satisfied). Too often, satisfaction surveys are really intended as library report cards. In fact, some surveys actually ask participants to assign the library a grade from A to F. There is usually no intent to take any remedial action based on replies to these questions, but rather to use the responses in negotiations with administrators in the sponsoring institution.

There is increased interest in satisfaction with libraries and their services, but the concept is not well linked to customers. The terms 
satisfaction and service quality are frequently used interchangeably; this mistake has led to more confusion. One new measures initiative has been the LibQUAL+ ${ }^{\mathrm{TM}}$ project. The LibQUAL+ ${ }^{\text {TM }}$ grew out of initial efforts to apply the widely used the SERVQUAL protocol (Parasuraman, Berry and Zeithaml,1991; Parasuraman, Zeithaml and Berry,1985,1994) in the library service contect (Thompson et al., 2002). The library survey LibQUAL+ ${ }^{\mathrm{TM}}$ is sometimes called a service quality survey and at other times a satisfaction survey. Adding to the confusion, those applying that instrument may view it as addressing outcomes. Satisfaction is an emotional reaction - the degree of contentment or discontentment — with a specific transaction or service encounter. Satisfaction may or may not be directly related to the performance of the library on a specific occasion. A customer can receive an answer to a query but be unsatisfied because of an upsetting or angry encounter. Conversely, although the query might remain unanswered, another customer might feel satisfied because the encounter was pleasant and the helper interested and polite.

Service quality is a complex concept: It has several dimensions beyond the content/ context and the performance/performanceexpectations gap. Service quality is both personal to individuals and collective among many customers. In a number of instances,

impressions of service quality can be changed; perceptions move up with positive experiences and down as a result of negative ones.

\section{Research Question}

Is a significant positive relationship between service affect, library as place, personal control, and information access with satisfaction of library user?

\section{LITERATURE REVIEW AND HYPHOTESIS}

Service quality on the Library

According to Parasuraman et al. (1988), service quality can be defined as an overall judgment similar to attitude towards the service and generally accepted as an antecedent of overall customer satisfaction (Zeithaml and Bitner, 1996). Parasuraman et al. (1988) have defined service quality as the ability of the organization to meet or exceed customer expectations. It is the difference between customer expectations of service and perceived service (Zeithaml et al., 1990). Perceived service quality results from comparisons by customers of expectations with their perceptions of service delivered by the suppliers (Zeithaml et al., 1990). If expectations are greater than performance, then perceived quality is less than satisfactory and hence customer dissatisfaction occurs (Parasuraman et al., 1985; Lewis and Mitchell, 1990).

Services unlike tangible products are produced and consumed at the same time in the presence of the customer and the service producer. The presence of the human element during the service delivery process greatly increases the probability of error on the part of employees and customers. This erroris duetointangible behavioral processes that cannot be easily monitored or controlled (Bowen, 1986). However, although a substantial amount of service quality research has focused on service customers' perceived service quality (Parasuraman et al., 1988; Carman, 1990; Parasuraman et al., 1991; Babakus and Boller, 1992; Cronin and Taylor, 1992; Babakus and Mangold, 1992), relatively little attention has been paid to exploring the factors that impact on service employees' behavior with regard to delivering service quality.

More than two decades ago, Surprenant and Solomon (1987) stated that service encounters are human interactions. They suggested that customers and service providers 
have roles to play during and possibly after service encounters and that these roles are based on "interpersonal interactions" between organizations and customers. Service quality in all service encounters is thus intrinsically affected by the perspectives of both the service provider and the service receiver. Similarly, Czepiel (1990) concluded that research on service quality must always include the perspectives of both the provider and the receiver.

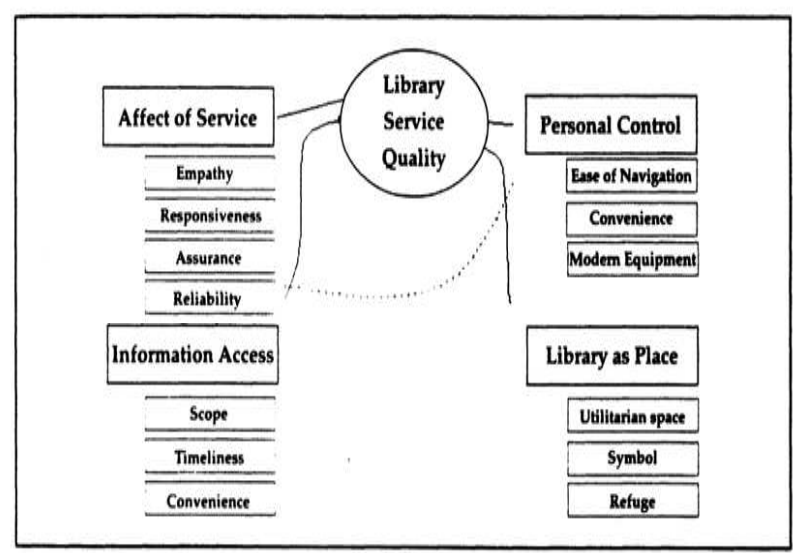

Model was the preferred model for the library assessment in this study. Nadiri and Mayboudi (2010) asserted that the LibQUAL Model is an instrument to measure the service quality of libraries and to help the librarians determine whether they have met the expectations of their users or not. LibQUAL, also known as a 'total market survey' of library's users, established by the Association of Research Libraries (ARL) with the cooperation of the Texas A\&MUniversity (TAMU) in 2000, provides an alternative means of measuring the quality of academic library services (Edgar, 2006). The LibQUAL survey evolved from a conceptual model based on the SERVQUAL instrument, which defines the service quality as "the difference between customers' perceptions and expectations". This instrument was re-grounded to better reflect the library context (Empey and Murphy, 2004 and Rehman, 2012).
The LibQUAL+ scale was developed to measure the user perception of library service quality consisting of 22 core items under three dimensions: (a) service effect, (b) library as place and (c) information control. It has been used in different countries (USA, Canada, Australia, New Zealand, UK, France, Ireland, Netherlands, Switzerland, Germany, Denmark, Finland, Norway, Sweden, Egypt, United Arab Emirates, and South Africa), and adopted in twelve different languages (Thompson et al., 2007). LibQUAL+ results are interpreted as scores on perceptions that compares against scores of what is reported to beminimally acceptable service, and what is reported to be desired service, which is called the zones of tolerance interpretation framework (Nadiri and Mayboudi, 2010). However, for the purpose of this study, the LibQUAL + survey tool was altered to address local conditions and preferences without challenging the designer's assertion that the statements fully reflectthe dimensions. Themodification of LibQUAL+instrument is discussed further in the survey design part of this paper.

The LibQUAL tool measures the service quality based on three dimensions: effect of service, information control and library as place. The instrument was built on the theoretical foundations of the gap theory of service quality (Cook and Thompson, 2000). The main characteristic of the gap analysis is that each item assessing services used by users is rated separately whereby scores based on similar scales are granted forminimum, desired and perceived levels of service. The minimum expectations are the level of service that users consider as adequate and this score represents their minimum level of service that users will tolerate or are willing to accept. The desired service level represents the level of service that customers hope to receive and the perceived service level describes the level of service that the library currently provides (Mohd Nazrul, 2009). 


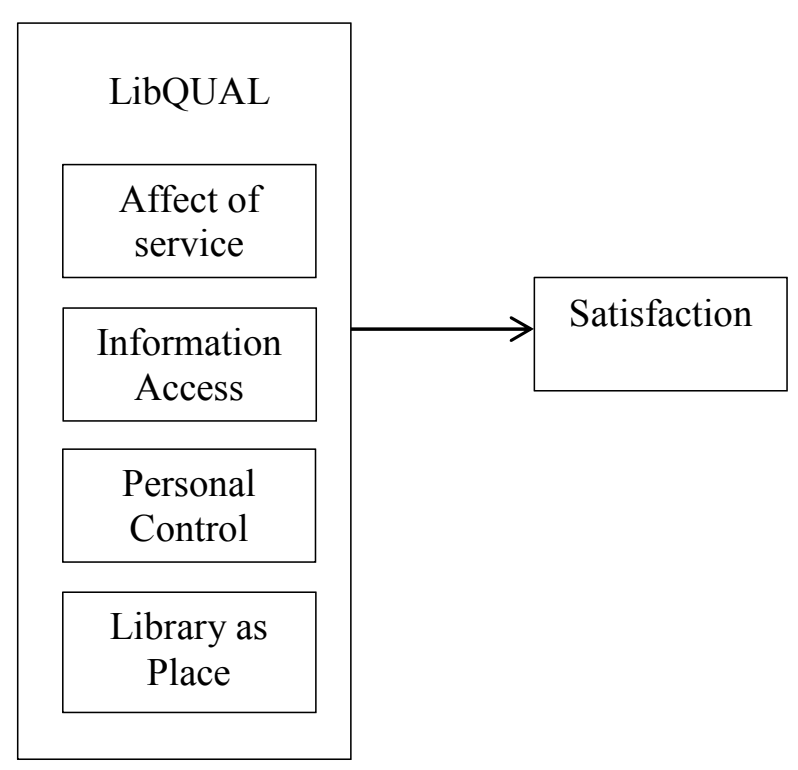

Figure 2

Research Model

$\mathrm{H}_{1}$ : There is a significant positive relationship between affect of service, information access, personal control, library as place with satisfaction of library user.

\section{RESEARCH METHOD}

In statistics, a population is a complete set of items that share at least one property in common that is the subject of a statistical analysis. In statistics and quantitative research methodology, a data sample is a set of data collected and/or selected from a statistical population by a defined procedure. Technic sampling used non probability sampling with purposive sampling. A survey of 250 respondents were administered to obtain customers' perceptions of the noted first-order dimensions. Responses to all items except the demographic questions were on a 5-point Likerttype scale, anchored by $1=$ totally agree and 5 $=$ totally disagree. Neither agree nor disagree at the scale midpointwas rated a 3. A 5-point Likerttype scale was used to increase response rate and response quality along with reducing respondents' "frustration level" (Babakus and Mangold 1992).

Responses to all items were on a 5-point Likert-type scale, anchored by $1=$ totally agree and 5 = totally disagree. Neither agree nor disagree at the scale midpointwas rated a 3. A 5-point Likert-type scale was used to increase response rate.

\section{Operational Variable}

\section{Service Affect}

1. Willingness to help users

2. Giving users individual attention

3. Employees deal with users caring fashion

4. Employees who are consistently courteous

5. Employees have knowledge answer question

6. Employees understand needs of users

7. Readines to respond to users' question

8. Employees who instill confidence in users

9. Dependability handling service problems

\section{Library as Place}

1. A have for quite and solitude

2. A meditative place

3. A contemplative environment

4. Space that facilitates quite study

5. A place for reflection and creativity

\section{Personal Control}

1. Website enabling me locate info on my own

2. Elec resources accessible home or office

3. Access tools allow me find on my own

4. Modern equipment me easily access info I need

5. Info easily accessible for independent use

6. Convenient access to library collection

\section{Information Access}

1. Comprehensive print collection

2. Complete runs of journal titles

3. Interdisciplinary library needs addressed

4. Timely document delivery/interlbrary loan

5. Convenient business hours 


\section{Satisfaction}

1. Satisfaction with service affect

2. Satisfaction with place of library

3. Satisfaction with personal of library

4. Satisfaction with information access

\section{Validity and Reliability}

The validity of a measuring instrument is whether validity of necessary to know the extent to which a measuring instrument used in research can measure what researchers actually want or can be used to test measuring instruments to study the results of the instrument can provide objective (Cooper and Schindler, 2001).

Table 1

Validity Outcome

\begin{tabular}{|c|c|c|c|c|c|c|}
\hline \multirow{2}{*}{ Variable } & \multirow{2}{*}{ Indicator } & \multicolumn{5}{|c|}{ Component } \\
\hline & & 1 & 2 & 3 & 4 & 5 \\
\hline $\begin{array}{l}\text { Service } \\
\text { affect }\end{array}$ & $\begin{array}{l}1.2 \\
1.3 \\
1.4 \\
1.5 \\
1.6 \\
1.7 \\
1.8 \\
1.9\end{array}$ & $\begin{array}{l}0,813 \\
0,550 \\
0,744 \\
0,814 \\
0,797 \\
0,795 \\
0,740 \\
0,763\end{array}$ & & & & \\
\hline $\begin{array}{l}\text { Library as } \\
\text { place }\end{array}$ & $\begin{array}{l}2.1 \\
2.2 \\
2.3 \\
2.4 \\
2.5\end{array}$ & & $\begin{array}{l}0,606 \\
0,887 \\
0,883 \\
0,853 \\
0,863\end{array}$ & & & \\
\hline $\begin{array}{l}\text { Personal } \\
\text { control }\end{array}$ & $\begin{array}{l}3.1 \\
3.2 \\
3.3 \\
3.4\end{array}$ & & & $\begin{array}{l}0,769 \\
0,647 \\
0,899 \\
0,831\end{array}$ & & \\
\hline $\begin{array}{l}\text { Information } \\
\text { access }\end{array}$ & $\begin{array}{l}4.1 \\
4.2 \\
4.3 \\
4.4\end{array}$ & & & & $\begin{array}{l}0,877 \\
0,841 \\
0,866 \\
0,621\end{array}$ & \\
\hline Satisfaction & $\begin{array}{l}5.1 \\
5.2 \\
5.3 \\
5.4 \\
5.5\end{array}$ & & & & & $\begin{array}{l}0,865 \\
0,890 \\
0,871 \\
0,864 \\
0,789\end{array}$ \\
\hline
\end{tabular}

Source: Primary data (2016)

Construct validity test is done by the validity confirmatory factor analysis. The analysis method is the one of the main purpose to summarize multivariate or reduce or variable be necessary data for analysis. Relating to solving problems factor analysis of the relationships between a relationship between that and the indicators signal into a dimension which gives the relationship. In question adopted as modified by previous studies and analysis conducted by the factor confirmatory.

Reliability test measuring instruments to test the accuracy of consistency among the items with a statement in an instrument . Measurement procedures relating to the accuracy of reliability and consistency. A measuring instrument that is considered it 's reliable if the gauge indicating that consistent results from time to time. Researchers tested research instruments with a sample of some 30 respondents. The coefficient of reliability alpha cronbach shown by the coefficients alpha is higher 0.6. The higher the value of the coefficients cronbach alpha means getting high reliability a measuring instrument used.

Tabel 2

Reliability Outcome

\begin{tabular}{|l|c|l|}
\hline \multicolumn{1}{|c|}{ Variable } & $\begin{array}{c}\text { Cronbach } \\
\text { Alpha }\end{array}$ & Result \\
\hline Service affect & 0,890 & Reliable \\
\hline Library as place & 0,878 & Reliable \\
\hline Personal control & 0,796 & Reliable \\
\hline Information access & 0,821 & Reliable \\
\hline Satisfaction & 0,909 & Reliable \\
\hline
\end{tabular}

\section{RESULT AND DISCUSS}

Table 3 shows the signicance of library as place, personal control, information access to users' satisfaction on services provided by the UAD Library. The results suggested that 0,532 of users' satisfaction affected by independent variable, and 0,468 affected by others factors. 
Table 3

\section{Hyphotesis Result}

\begin{tabular}{|l|c|c|}
\hline \multicolumn{1}{|c|}{ Variable } & Significance & Hyphotesis \\
\hline Service affect & 0,592 & Not supported \\
\hline Library as place & 0,010 & Supported \\
\hline Personal control & 0,000 & Supported \\
\hline Information access & 0,026 & Supported \\
\hline
\end{tabular}

Studies on users' perceptions of service quality level have focused primarily on finding ways to meet or exceed users' expectations. The concept of measuring the gap score between users' perceptions of delivered services and minimum service level which they think is adequate and the ideal level of desired service has proven to be very useful for evaluating levels of library service quality. This study applied a customized survey instrument which was developed based on the LibQUAL Model, composed of 30 items for measuring the level of four service quality dimensions and user satisfaction of services provided.

From the survey results, it can be concluded that the area of strength for UAD libraries was the staff by which the respondents felt that the staff showed not courteous behaviour, not individual attention and not confidence in delivering services. The results also recommended that the library collection was the area of greatest concern; they expected amore extensive provision of digital resource collections, a more userfriendly E-resource Portal and more organized record collections.

The information gathered from this study,which focuses on examining the quality of library services and its users' satisfactionmay provide valuable input for the management of the university to improve the level of service quality and the overall satisfaction of the students. Additionally, the results from this study will serve as a guideline for other academic libraries to improve their services and as a reference for further research in related fields. Parasuraman et al. (1994) claimed that accurate measure of service quality is deemed critical and measuring only customers' perceptions alone is not enough as this does not provide maximum diagnostic value and might provide misleading conclusions. Hence a more detailed and comprehensive assessment of service quality such as the examination of zone of tolerance remains to be performed in other studies.

\section{SUMMARY}

Global competition among academic institutions has compelled university libraries to transform their conventional services and traditional roles to a more sophisticated, all-round service provider that can deliver their best services to their users. University libraries must cater the expansion of information sources, the high demand of users and information application as well as high student enrolments and competition among service sectors.

The ability of an academic library to fulfill its user expectationswill yield user satisfaction for its services. Primarily, research on assessing users' perception on the level of service quality focuses on finding ways tomeet or exceed users' expectations. This study nevertheless aimed to measure students' perception and their satisfaction level of services provided by the UAD library and customized a new measuring tool on service quality and perspectives of library users based on the LibQUAL Model. A customized survey instrument was developed based on the model, consisting of 30 items measuring the level of four service dimensions and user satisfaction with an additional five items examining user satisfaction on general services. The Cronbach's alpha range is from 0.796 to 0.909 , which was adequately greater than the recommended value of 0.7 , thus exhibiting good internal reliability of the constructs. The result of the study reported positive values for both gap 
analyses in all service quality dimensions. Based on 97 respondent feedbacks, results showed that the perceived service quality level exceeded users' acceptable level on minimum service and desired service. Specifically, the users are satisfied with the services provided. Results from this study serveas a guide for effective decision making by the library in its administration and resource allocation to ensure accomplishment of the library's vision and mission.

\section{REFERENCES}

Adeniran, P. (2011). User satisfaction with academic libraries services: Academic staff and students' perspectives. International Journal of Library and Information Science, 3(10), 209-216.

Carman, J.M.(1990). Consumer perceptions of service quality: An assessment of SERVQUAL dimensions. Journal of Retailing,66,33-55.

Cook and Thompson, (2000) Cook, C., and Thompson, B. (2000). Reliability and validity of SERVQUAL scores used to evaluate perceptions of library service quality. The Journal of Academic Librarianship, 26(4), 248-258.

Cronin, J.J., and Taylor, S.A.(1992). Measuring service quality: A reexamination and extension. Journal of Marketing, 56, 5568.

Didomenico, E., and Bonnici, J. (1996). Assessing service quality within the educational environment. Education, 116(3), 353359.

Edgar, B. (2006). Questioning LibQUAL+: Critiquing its assessment of academic library effectiveness, 69th Annual Meeting of the American Society for Information Science and Technology (ASIST), Austin (US) 3-8 November.
Empey and Murphy, 2004 Empey, H., and Murphy, J. A. (2004). Analysis of the results of participation in the LibQual+ Survey 2003. University of Northern British Columbia

Mohd Nazrul, Mohd. Nazrul, Z. A. (2009). International student perception on Perpustakaan Sultanah Zanariah (PSZ) as academic facility.

Nadiri, H., and Mayboudi, S. M. A. (2010). Diagnosing university students' zone of tolerance from university library services. Malaysian Journal of Library and Information Science, 15(1), 1-21.

Parasuraman, A., Zeithaml, V.A., and Berry, L.L. (1985). A conceptual model of service quality and its implications for future research. Journal of Marketing, 70, 4150 .

Parasuraman, A., Zeithaml, V. A., and Berry, L. L. (1994). Alternative scales for measuring service quality: A comparative assessment based on psychometric and diagnostic criteria. Journal of Retailing, 70(3), 201-230.

Parasuraman, A., Berry, L.L., and Zeithaml, V.A. (1988). SERVQUAL: A multipleitem scalefor measuring customer perceptions ofservice quality. Journal of Retailing, 64, 12-40.

Pedramnia, Modiramani and Ghanbarabadi (2012). An analysis of service quality in Academic libraries using LibQUAL scale. Library Management, 33(3), 159167

Rehman, 2012 Rehman, S. U. (2012). Understanding the expectations of Pakistani libraries users: A LibQUAL study. Library Philosophy and Practice Paper 732. 
Roslah, J., and Zainab, A. N. (2007). Identifying what services need to be improved by measuring the library's performance. Malaysian Journal of Library and Information Science, 12(1), 35-53.

Shoeb, Z. H. (2011). Identifying service superiority, zone of tolerance and underlying dimensions: Service quality attributes in a private university library in Bangladesh. Library Review, 60(4), 293-311.
Thompson et al., 2007 Thompson, B., Kyrillidou, M., and Cook, C. (2007). Library user's service expectations: $A$ LibQUAL+ study of the range of what users will tolerate. Paper presented at the 7th Northumbria Conference on Performance Measurement in Libraries and InformationServices, Stellenbosch, South Africa August 13, 2007.

Zeithmal, V. A., Berry, L. L., and Parasuraman, A. (1993). The nature and determinants of customer expectation of service. Journal of the Academy of Marketing Science, 21(1), 1-12. 
koefisien variable pertumbuhan penjualan sebesar -0,00007. Hal ini bermakna bahwa setiap kenaikan 1\% pertumbuhan perusahaan akan menurunkan kinerja perusahaan sebesar 0,007\%. Jadi untuk hipotesis 1 dalam penelitian ini terdukung, siginifikan pada level $15 \%$.

2) Pertumbuhan penjualan berpengaruh positif terhadap kebijakan penggunaan utang perusahaan

Langkah yang kedua ini sekaligus menguji hipotesis 2 penelitian ini serta menjawab rumusan masalah apakah perusahaan yang memiliki pertumbuhan penjualan tinggi akan cenderung menggunakan utang dalam kebijakan pendanaannya. Tabel VIII menampilkan hasil pengujian statistiknya.

\section{Tabel 2}

Pertumbuhan Penjualan dan Kebijakan Penggunaan Hutang Perusahaan

\begin{tabular}{|l|l|}
\hline & Debt to Equity Ratio (DER) \\
\hline $\begin{array}{l}\text { Pertumbuhan } \\
\text { Penjualan }\end{array}$ & $\begin{array}{l}0,037^{* *} \\
(1,63)\end{array}$ \\
\hline
\end{tabular}

**signifikan pada level $10 \%$

Berdasarkan Tabel 2, perusahaan dengan tingkat pertumbuhan yang tinggi akan cenderung meningkatkan penggunaan utang dalam keputusan pembiayaannya. Berdasarkan hasil uji statistik, 1\% peningkatan penjualan akan direspon dengan peningkatan $3,7 \%$ penggunaan utang. Hasil pengujian ini signifikan pada level $10 \%$ dan mendukung hipotesis yang kedua.

3) Pengaruh penggunaan utang terhadap kinerja perusahaan

Langkah berikut adalah langkah ketiga dari prosedur yang dikemukakan oleh Baron, dan Kenny (1986). Pengujian ini akan melihat efek dari penggunaan utang terhadap kinerja perusahaan. Tabel IX menampilkan hasil pengujian statistiknya.
Tabel 3

Pengaruh Penggunaan Hutang Terhadap Kinerja Perusahaan

\begin{tabular}{|l|c|}
\hline & Kinerja Perusahaan \\
\hline Debt to Equity & $0,0009^{*}$ \\
Ratio (DER) & $(1,53)$ \\
\hline
\end{tabular}

*signifikan pada level 15\%

Berdasarkan Tabel 3, penggunaan utang sebagai model kebijakan pembiayaan berpengaruh positif terhadap kinerja perusahaan. Atau dengan kata lain, 1\% kenaikan utang yang digunakan akan meningkatkan kinerja perusahaan sebesar 0,09\%. Hal ini tidak seperti yang diduga dalam penelitian ini. Dalam penelitian ini diduga bahwa kebijakan penggunaan utang berpengaruh negatif terhadap kinerja perusahaan. Karena penggunaan utang dipandang sebagai sebuah risiko yang dapat menurunkan kinerja perusahaan. Maka dari itu, hipotesis 3 yang menyatakan bahwa manajer berperilaku reaktif dalam kebijakan pendanaan tidak didukung dalam penelitian ini.

4) Pengujian pengaruh kebijakan utang, dan pertumbuhan penjualan terhadap kinerja perusahaan.

Langkah keempat ini adalah langkah terakhir dari prosedur Baron, dan Kenny (1986) untuk mengetahui efek mediasi dari kebijakan penggunaan utang. Dikatakan memediasi ketika nilai koefisien variabel independen pada pengujian poin (a) menjadi tidak signifikan ketika variabel mediasi (DER) dimasukkan dalam model. Pengujian ini sebenarnya akan digunakan sebagai penguji perilaku reaktif manajer dalam pengambilan keputusan kebijakan keuangan, dengan dugaan awal pertumbuhan penjualan berpengaruh negatif terhadap kinerja, kemudian pertumbuhan penjualan berpengaruh positif terhadap kebijakan penggunaan utang dan kebijakan 
penggunaan utang berpengaruh negatif terhadap kinerja. Dikatakan reaktif adalah ketika peningkatan penggunaan utang diambil oleh manajer ketika perusahaan sedang mengalami pertumbuhan penjualan yang kemudian dampaknya terjadi penurunan kinerja perusahaan. Akan tetapi, pengujian langkah ketiga justru menyatakan sebaliknya bahwa peningkatan penggunaan utang berpengaruh positif terhadap kinerja.

\section{Tabel 4}

Pengaruh Kebijakan Hutang, dan Pertumbuhan Penjualan Terhadap Kinerja Perusahaan

\begin{tabular}{|l|l|}
\hline & Kinerja Perusahaan (DV) \\
\hline $\begin{array}{l}\text { Pertumbuhan } \\
\text { Penjualan (IV) }\end{array}$ & $-0,00008^{* *}$ \\
& $(1,65)$ \\
Debt to Equity Ratio & $0,0002 * *$ \\
(MV) & $(-1,70)$ \\
\hline
\end{tabular}

**signifikan pada level $10 \%$

Berdasarkan Tabel 4, yang digunakan sebagai pengujian variabel mediasi tidak didukung. Dikatakan memediasi adalah ketika variabel mediasi (MV) dimasukkan dalam model maka variabel independen (IV) menjadi tidak signifikan. Dari hasil pengujian bahkan nilai koefisien IV tidak melemah tapi justru menjadi semakin kuat. Hal ini berimplikasi bahwa kebijakan utang tidak memediasi hubungan atara pertumbuhan penjualan dengan kinerja perusahaan.

\section{KESIMPULAN DAN SARAN}

Berdasarkan hasil penelitian ini, perusahaan yang berada pada fase pertumbuhan akan cenderung memiliki kinerja yang buruk dimasa yang akan datang. Hal ini dibuktikan dengan hasil uji statistik yang menyatakan bahwa pertumbuhan penjualan berpengaruh negatif terhadap kinerja perusahaan. Hasil penelitian ini setidaknya mengamini beberapa fenomena dalam dunia bisnis, bahwa beberapa perusahaan justru bangkrut ketika berada pada masa pertumbuhan. Hal ini mengingatkan kembali apa yang pernah Jim Collins katakana bahwa "good is the enemy of great", atau dengan kata lain bahwa kondisi yang dianggap bagus merupakan musuh utama dari kejayaan. Penelitian ini sebenarnya ingin mengurai fenomena tersebut dengan mengambil entry point penggunaan utang yang digunakan oleh perusahaan. Penggunaan utang dipandang sebagai sebuah kebijakan yang berisiko yang diambil secara reaktif oleh manajer sehingga berdampak buruk pada kinerja perusahaan. Akan tetapi hal itu tidak terbukti dalam penelitian ini. Yang terjadi justru sebaliknya bahwa kebijakan utang justru berdampak bagus bagi perusahaan, ini ditunjukkan dengan pengujian statistik pengaruh antara kebijakan penggunaan utang dengan kinerja perusahaan. Kebijakan penggunaan utang ketika perusahaan sedang tumbuh merupakan keputusan rasional seorang manajer yang mesti diambil, mengacu pada hasil penelitian ini. Jadi paradox tentang perusahaan yang sedang tumbuh dan memburuk dalam kinerja pada masa yang akan datang dalam penelitian ini belum teruraikan secara jelas. Akan tetapi yang pasti bahwa perusahaan yang sedang tumbuh rawan terjebak pada kebangkrutan terbukti dalam penelitian ini.

\section{DAFTAR PUSTAKA}

Anderson, C, Ronald. Mansi, A, Sattar. dan Reeb, M, David. (2003). Founding family ownership and the agency cost of debt. Journal of Financial Economics, 68, 263-285

Baron, R.M., dan Kenny, D.A.(1986). The Moderator-Mediator Variable Distinction in Social Psycological Research: Conceptual, Strategies, and Statistical Considerations. Journal of 
Personality and Social Psycology, 51, 1173-1182

Billet, T, Matthew. King, Tao-Hsien Dolly. dan Mauer, David. (2007). Growth Opportunities and the Choice of Leverage, Debt Maturity, and Covenants. The Journal of Finance, Vol. 62, No. 2, pp. $697-730$

Campello, Murillo. (2006). Debt financing: Does it boost or hurt firm performance in product markets?. Journal of Financial Economics, 82, 135-172

Gombola, Michael. dan Marciukaitye, Dalia. (2007). Managerial Overoptimism and the Choice between Debt and Equity Financing. The Journal of Behavioral Finance, Vol.8, No. 4, 225-235

Heaton, J.B. (2002). Managerial Optimism and Corporate Finance. Financial Management, Vol. 31, No. 2 (Summer, 2002), pp. 33-45.

Jensen, C, Michael. dan Meckling, H, William. (1976). Theory of the Firm: Managerial Behavior, Agency Costs and Ownership Structure. Journal of Financial Economics, V. 3, No. 4, pp. 305-360

Marciukaitye, Dalia. dan Szewczyk, H, Samuel. (2011). Financing Decisions and Discretionary Accruals: Managerial Manipulation or Managerial Overoptimism. Review of Behavioral Finance, 3, 91-114
Ramezani, A, Cyrus. Soenan, Luc. dan Jung, Alan. (2002). Growth, Corporate Profitability,and Value Creation. Financial Analyst Journal, November/ December 2002

Serrasqueiro, Ze'lia Silva. Armada, Manuel, Rocha. dan Nunes, Paulo, Macas. (2011). Pecking Order Theory versus Trade-Off Theory: are Service SMEs' capital structure decisions different? Service Business, 5, 381-409

Syam-Sunder, Lakhsmi. dan Myers, C, Stewart. (1999). Testing static trade of against pecking order models of capital structure. Journal of Financial Economics, 219244

Van Der Steen, Eric. (2004). Rational Overoptimism (and Other Bias). The American Economic Review, 94, 4, pg. 1141

Weinstein, D, Neil. (1980). Unrealistic Optimism about Future Life Events. Journal of Personality and Social Psychology, Vol. 39, No. 5, 806-820

Wu, Xeiping. dan Yeung, Kin Au, Chau. (2012). Firm Growth and Capital Structure Persistence. Journal of Business \& Banking, 36, 3427-3443

Yi, Jong-Hwan. (2001). Pre-offering earnings and the long-run performance of IPOs. International Review of Financial Analysis, 53 - 67. 